\title{
China's new problems of food security revealed by the Food Equivalent Unit
}

\author{
Huilong LIN (凶), Ruichao LI, Cangyu JIN, Chong WANG, Maohong WEI, Jizhou REN \\ State Key Laboratory of Grassland Agro-Ecosystems, College of Pastoral Agriculture Science and Technology, \\ Lanzhou University, Lanzhou 730020, China
}

\begin{abstract}
China's food security has a great influence on the world, and has always been the top priority in China. In recent years, as the concept of food security is evolving into one of nutrition security and the importance of food diversity is increasing, research based on nutrition security and broad food systems are increasingly needed in today's China. Thus, not only grain for human consumption, but also animal foods have been integrated into the Food Equivalent, which is used to analyze China's current agriculture system and reveal the water resource distribution. The results indicated that the average animal food consumption has risen by $78.6 \%$, and now China's daily supply of animal food per capita has reached about $50 \%$ of that in the USA and $80 \%$ of that in the South Korea. So there exist an obvious disparity in animal food supply between China and these two countries. It is impossible for the China's current agricultural system to achieve the level in the USA. Under China's current agricultural system, the consumption proportion of feed grain had surpassed the consumption of food grain, increased sharply from $33 \%$ in 1992 to $67 \%$ in 2011. However, the growth potential of total grain output is approaching an upper limit, so the continued growth of feed grain demand exerts great pressure on the China's food supply. The discordance of the spatial distribution of water resource and virtual water revealed that China's current agriculture system had a low efficiency in being able to achieve food and nutrition security. China's current "grain farming" cannot meet the demand of increasing nutrition and appropriate resource utilization. The implementation of grassland agriculture appears feasible and necessary for saving feed grain, providing a large number of high-quality animal foods and appropriate water resource utilization.
\end{abstract}

Keywords food security, nutrition security, food equivalent unit, grassland agriculture, China

Received April 18, 2014; accepted May 4, 2014

Correspondence: linhuilong@1zu.edu.cn

\section{Introduction}

In 1995, Lester Brown mentioned in his book [1] that China's land scarcity will become everyone's land scarcity; water scarcity in China will affect the entire world; China's dependence on massive imports will be a wake-up call that we are colliding with the earth's capacity to feed us. Water is a hugely important factor in the use of land, and, it is the shortage of water resources that mainly impacts China's food security [2]. His results have attracted worldwide attention about food security in China. How to use $7 \%$ of world's cultivated land and $8 \%$ of fresh water to feed China's $22 \%$ of world's population has become a huge problem for world food security [3,4]. A focus on food security was instigated by FAO when the Committee on World Food Security (CFS) was established in 1974. The concept of food security has shifted several times and is now defined as a condition when all people at all times consume food of sufficient quantity and quality in terms of variety, diversity, nutrient content and safety to meet their dietary needs and food preferences for an active and healthy life, coupled with a sanitary environment, adequate health and care [5]. With diverse farming systems, agricultural biodiversity and diversity of diet becoming more important [6,7], food security has now evolved into nutrition security. The field of food is very broad, and can be divided into mineral food, plant food and animal food [8]. Plant food refers to the grains, fruits, vegetables, algae, etc., while animal food refers to meat, milk and eggs, and mineral food refers to salt and some mineral elements which supply the essential nutrient elements for humans. Plant food and animal food provide all calories and protein which humans need to survive. So plant and animal food should be integrated in food security measurement.

China's current agriculture system could be defined as "grain farming." Grain farming is one of the oldest agriculture systems in the world, with the grain the staple crop and pigs the major livestock. Ren [9] reported that 
about 460 million pigs are feed in China and 50\% of the world's pork is produced in China. So the grain farming is also called "pig and grain" agriculture. In this farming system, pig manure is used to improve soil fertility and hopefully to improve the grain output; the grain harvest is partly used to feed pigs and the human diet is mainly on grain and pork. It is the current feeding practice, with grain the major animal feed and forage crops a relatively minor feed source that drives this phenomenon. Because of the high cost of feeding animals in the current system, pigs that have a comparatively high rate of return on fodders have a most important place in the animal products market. While poultry and other grain-fed animals, which also are very import source of protein through meat and eggs in China, has exacerbated this predicament. Herbivores, which have a comparatively low rate of return on fodders, remain a small proportion of animal production in China. Grain demands come from food, feed, processing and seed use. Since the 1990s, food and feed grain have occupied a dominant position of the total grain demand in China [10]. It is believed that with the increasing demand of animal products, future demand for feed grain will be a major pressure on grain production and prices.

In China, despite the consumption of pork and other animal food, food is narrowly defined as grain. China's food security is equated with "grain security" as well. Almost all research on China's "food security" focuses on the "grain security" [3,11,12]. China's food security evaluation system is highly complex, involving grain output, degree of self-sufficiency, per capita occupancy volume, price and average income, etc. $[13,14]$. Almost all of these indicators focus on grain instead of food as a whole, and high output of grain has been regarded as the first and primary target to ensure food security. These indicators make the study based on them analyzed China's grain markets in some degree, and simplify the data collection and analysis by only focusing on grain. However, animal food, which provides high-quality protein for people, has been almost ignored, and food diversity neglected. So integrity of food diversity in a common food equivalent is urgently needed to evaluate the actual food security in today's China.

In this study, not only grain, but also animal food is analyzed to assess China's food and nutrition security. When analyzing food security, calculating total of food is an important step, but it is not appropriate to simply add them together because different kinds of food have different nutritional value. So a unified food conversion system is introduced, namely the Food Equivalent Unit [8], which can place different kinds of food into a common food equivalent for further calculation. The purposes of this study were to analyze: (1) people's diet structure and make comparisons with the USA and Republic of Korea (South Korea) in order to reveal the trend of food consumption, by using Food Equivalent Unit to unify different kinds of food; (2) grain demand structure and the increasing trend of grain output to reveal the grain pressure in China, by using the Hodrick-Prescott filter [15]; and (3) the rationality of water resource utilization as a representative of resources, by contrasting the distribution of water resource and virtual water [16]. These analyses are to estimate the sustainability and stability of China's agriculture system and food security.

\section{Materials and methods}

\subsection{Data acquisition}

The statistics such as urban and rural population, per capita consumption of different kinds of food from 1992 to 2011 at regional, provincial and national scale, and the area and water resource of every province in 2011 were obtained from the National Bureau of Statistics of China. The database of the average dietary energy and protein supply derived from animal food in China, South Korea and the USA from 1990 to 2009 were from the FAO [17]. The grain consumptions to produce unit animal food in China (Table 1) were from 2002's statistics of the Development Planning Department of Ministry of Agriculture [18]. Virtual water is the water needed to produce agricultural commodities [16]. The virtual water contents in consuming water for per unit of grain production (Appendix A) among different provinces of China are from Sun and Zhang [19].

Food grain and feed grain are approximately considered as the whole demand of grain in the analysis. The calculated quantity of food grain was a conservative estimate, because data on soybean oil, bean products and food consumed outside the household were not included in the food equivalent analysis due to limitation of data resources. In China, the central government controls the self-sufficiency rate of grain to a high degree $(>95 \%)$, so the no data on import and export grain were included. This decision was made on the assumption that the import and export grain would not affect the overall result.

\subsection{Calculating demand structure and growth potential of grain output}

By multiplying per capita food consumption with the population, food grain consumption would be estimated. The quantity of feed grain consumption was estimated

Table 1 Grain consumption to produce unit animal food [18]

\begin{tabular}{lccccc} 
Table 1 & & & \multicolumn{2}{c}{$\mathrm{unit}_{\mathrm{kg}} \cdot \mathrm{kg}^{-1}$} \\
\hline Grain consumption & Pork & Beef and mutton & Poultry & Eggs & Milk \\
\hline
\end{tabular}


according to multiplying grain consumption that needed to produce a unit animal food (Table 1) by the output of each kind of animal food.

Hodrick-Prescott (H-P) filter which is a mathematical tool to separate the cyclical component of a time series from raw data [15] was used to separate the cyclical component from grain yield (EViews 6.0 software [15]) and reveal the underlying trends in grain yield from 1978 to 2011 .

\subsection{Estimating dietary structure}

Food Equivalent Unit (FEU) is a coefficient of conversion for a common food equivalent to value the edibleness of different kinds of food [8], including plant FEU and animal FEU. Food Equivalent (FE) is the measurement to integrate plant and animal food by multiplying relevant FEU to realize different kinds of food into a common food equivalent in the unified food conversion system.

Setting $100 \mathrm{~g}$ rice as a plant equivalent standard, the plant FEU is calculated by:

$$
\mathrm{FEU}_{\mathrm{p}}=H / 1585.0+P / 77.0
$$

Setting $100 \mathrm{~g}$ mutton as an animal equivalent standard, the animal FEU is calculated by:

$$
\mathrm{FEU}_{\mathrm{a}}=H / 6676.0+P / 21.6
$$

where $H$ is the energy contents in $100 \mathrm{~g}$ food in kilojoules; $P$ is the quantity of protein contents in $100 \mathrm{~g}$ food in grammes [8].

The conversion formula from animal $\mathrm{FEU}_{\mathrm{a}}$ to plant $\mathrm{FEU}_{\mathrm{p}}$ according to the Lindeman's efficiency [20] is:

$$
\mathrm{FEU}_{\mathrm{a}}=\mathrm{FEU}_{\mathrm{p}} / 10
$$

The tables of FEUs for main kinds of food are listed in Appendix B. Per capita consumption of food was calculated and turned into the common Food Equivalent to reveal the real dynamics of dietary structure in China (Appendix B).

Energy and protein supply of animal source from 1990 to 2009 in the USA and South Korea were compared with China in order to reveal China's current nutrition level.

\subsection{Analyzing water resources utilization}

By multiplying the amount of virtual water content per unit grain by grain output, the virtual water consumption of every province was estimated. A map of virtual water per unit area for each province in China was drawn using ArcGIS software. A map of water resource for each province was also drawn as baseline for comparison with the virtual water distribution.

\section{Results}

\subsection{Current tension derived from feed grain demand}

The consumption ratio of feed to food grain ranged from $33 \%$ in 1992 to $67 \%$ in 2011. During these 20 years, the consumption of feed grain increased at least 215 million tons with an average annual growth rate of $5.3 \%$, and has exceeded the consumption of food grain. It seems that the increasing trend will continue in the medium term. The balance has already shifted toward feed grain (Fig. 1).

However, the growth potential of grain yield is limited. According to cyclical component of H-P filter (Fig. 2), the grain yield wave from 1978 to 2011 was divided into four cycles from crests to troughs, neglecting the slight fluctuation which is smaller than 10 million tons. The first cycle was from 1978 to 1985 , spanning 8 years, with a crest of 27 million tons. The second was from 1986 to 1999, spanning 14 years, with a crest of 21 million tons. The third was from 2000 to 2009 , spanning 9 years, with a crest of 11 million tons. The fourth began in 2010 and was in progress at the time of writing. Three complete cycles from 1978 to 2009 had a decreasing tendency of wave crest, which indicated the increase speed is slowing. Since 2004 the fluctuation intensity has been convergent and it was smaller than that of $1980 \mathrm{~s}$. This means that the growth potential of grain yield in China is reaching a limit.

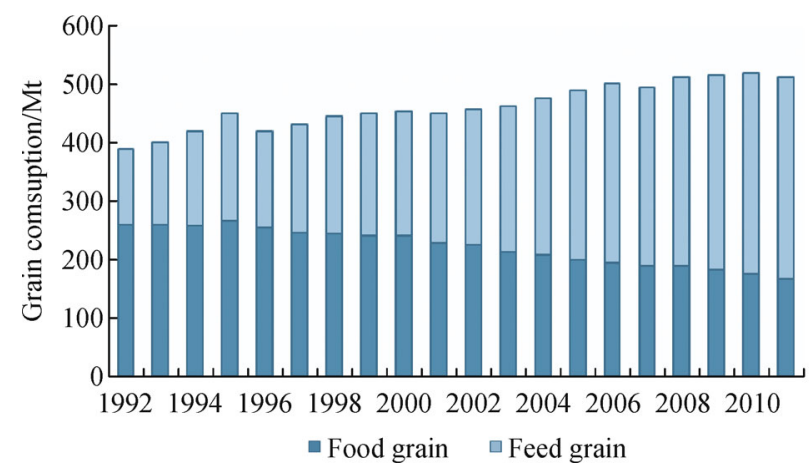

Fig. 1 Change in consumption of food and feed grains in China from 1992 to 2011 


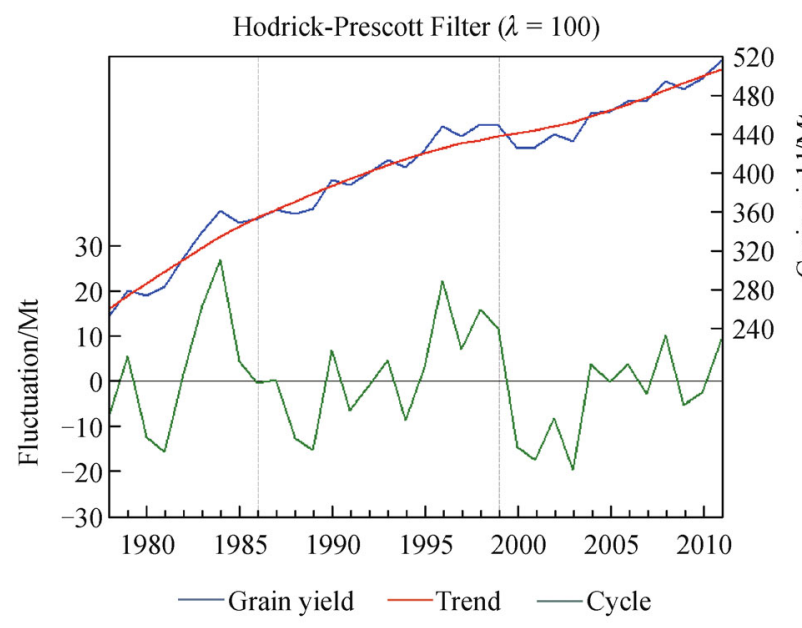

Fig. 2 H-P filter analysis of grain yield in China from 1978 to 2011

\subsection{Changing dietary structure}

Analysis on the changes of residents' food consumption from 1992 to 2011 showed that the $\mathrm{FE}_{\mathrm{a}}$ of average animal food consumption had a rise of $79 \%$, while the $\mathrm{FE}_{\mathrm{p}}$ of average plant food consumption had a drop of $44 \%$ (Fig. 3). The dietary structure of residents increased during 1992 to 2011 because the proportion of animal food grew from $44 \%$ to $72 \%$ of the total FE. Among the animal food products, pork showed the slowest rate of increase (1.7\%) but still represented a large proportion of $33 \%$ of animal food, and was the leading animal food consumed in China. Milk had the highest rate of increase rate $(9.5 \%)$ but occupied the smallest proportion of animal food (3.9\%) (Fig. 4). Overall, the FE of residents' food consumption integrating both plant and animal food increased from 397 $\mathrm{kg}$ in 1992 to $439 \mathrm{~kg}$ in 2011 (Fig. 3).

International comparison shows that during 1990 and 2009 , the per capita energy and protein supply from animal source in the USA was relatively stable at about 109 and

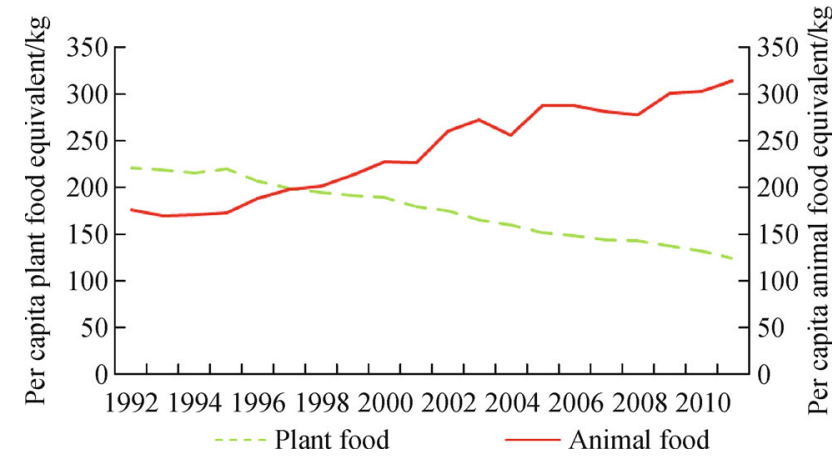

Fig. 3 Changes in per capita food consumption in China from 1992 to 2011

$73 \mathrm{~g} \cdot \mathrm{d}^{-1}$, respectively (Table 2 ). Per capita energy and protein supplies from animal food in the South Korea increased from 56 to $72 \mathrm{~g} \cdot \mathrm{d}^{-1}$ and 28 to $41 \mathrm{~g} \cdot \mathrm{d}^{-1}$, respectively, over the same period (Table 2). In China, the proportion of energy from animal food source rose from 32 to $59 \mathrm{~g} \cdot \mathrm{d}^{-1}$ and the proportion of protein from animal food source rose from 15 to $37 \mathrm{~g} \cdot \mathrm{d}^{-1}$ (Table 2). Despite the increase of animal food, there still exists an obvious gap in animal food supply between China and the other two countries. At present, China's per capita daily supply of animal food has only reached about half of that in the USA level and $80 \%$ of that in the South Korea.

\subsection{Utilization of water resources}

The spatial distribution of water resource and virtual water per unit area were distinctly different. The spatial distribution of per unit area water resource appears to increase from north to south (Fig. 5). While the per unit area virtual water is maximum in the middle of China, and shows a gradual decrease to the periphery, except Sichuan and Heilongiiang provinces (Fig. 6). It shows that in the water-scarce provinces such as Heilongjiang, Henan and Shandong, and provinces including Anhui and Jiangsu

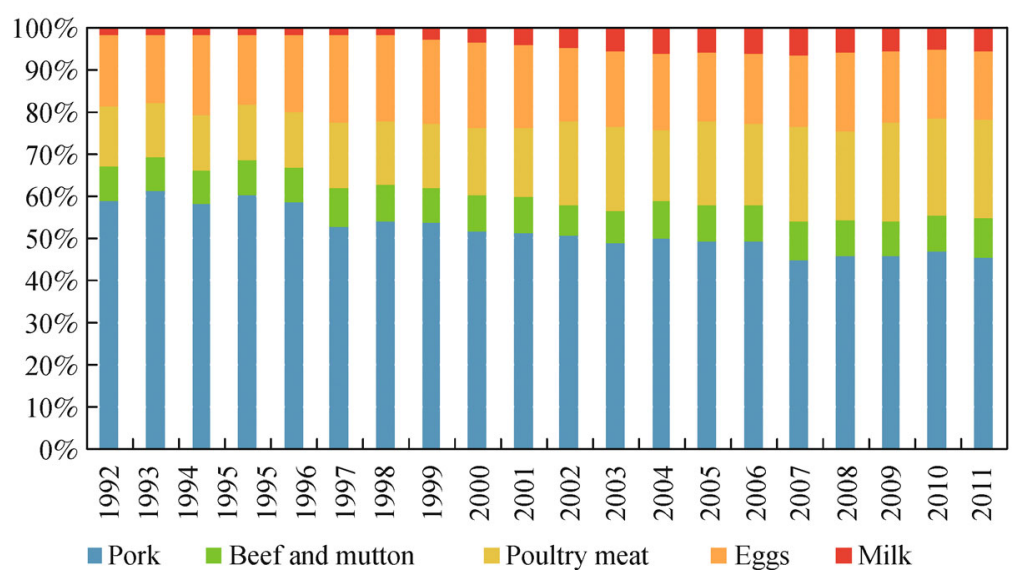

Fig. 4 The dietary structure of residents in per capita animal food consumption in China from 1992 to 2011 
Table 2 Comparisons of animal food supply between China, South Korea and the USA [5]

\begin{tabular}{|c|c|c|c|c|c|c|}
\hline \multirow[t]{2}{*}{ Year } & \multicolumn{3}{|c|}{$\begin{array}{c}\text { Per capita energy supply } \\
\text { derived from animal food } /\left(\mathrm{g} \cdot \mathrm{d}^{-1}\right)\end{array}$} & \multicolumn{3}{|c|}{$\begin{array}{c}\text { Per capita protein supply } \\
\text { derived from animal food } /\left(\mathrm{g} \cdot \mathrm{d}^{-1}\right)\end{array}$} \\
\hline & China & South Korea & USA & China & South Korea & USA \\
\hline 1990-1992 & 32 & 56 & 104 & 15 & 28 & 70 \\
\hline 1991-1993 & 33 & 57 & 105 & 17 & 30 & 70 \\
\hline 1992-1994 & 36 & 59 & 107 & 19 & 32 & 71 \\
\hline 1993-1995 & 38 & 59 & 107 & 21 & 33 & 72 \\
\hline 1994-1996 & 40 & 59 & 105 & 23 & 34 & 72 \\
\hline 1995-1997 & 42 & 60 & 104 & 24 & 34 & 71 \\
\hline 1996-1998 & 42 & 60 & 105 & 26 & 34 & 71 \\
\hline 1997-1999 & 43 & 62 & 108 & 27 & 35 & 72 \\
\hline 1998-2000 & 44 & 64 & 109 & 28 & 35 & 73 \\
\hline 1999-2001 & 46 & 65 & 110 & 29 & 36 & 73 \\
\hline 2000-2002 & 47 & 67 & 112 & 29 & 37 & 74 \\
\hline 2001-2003 & 47 & 67 & 112 & 30 & 38 & 74 \\
\hline 2002-2004 & 48 & 69 & 114 & 31 & 38 & 75 \\
\hline 2003-2005 & 50 & 69 & 114 & 32 & 38 & 75 \\
\hline 2004-2006 & 51 & 70 & 114 & 33 & 39 & 75 \\
\hline 2005-2007 & 52 & 70 & 112 & 34 & 41 & 75 \\
\hline 2006-2008 & 54 & 72 & 111 & 35 & 42 & 75 \\
\hline 2007-2009 & 56 & 73 & 110 & 36 & 41 & 74 \\
\hline 2008-2010 & 59 & 72 & 109 & 37 & 41 & 73 \\
\hline
\end{tabular}

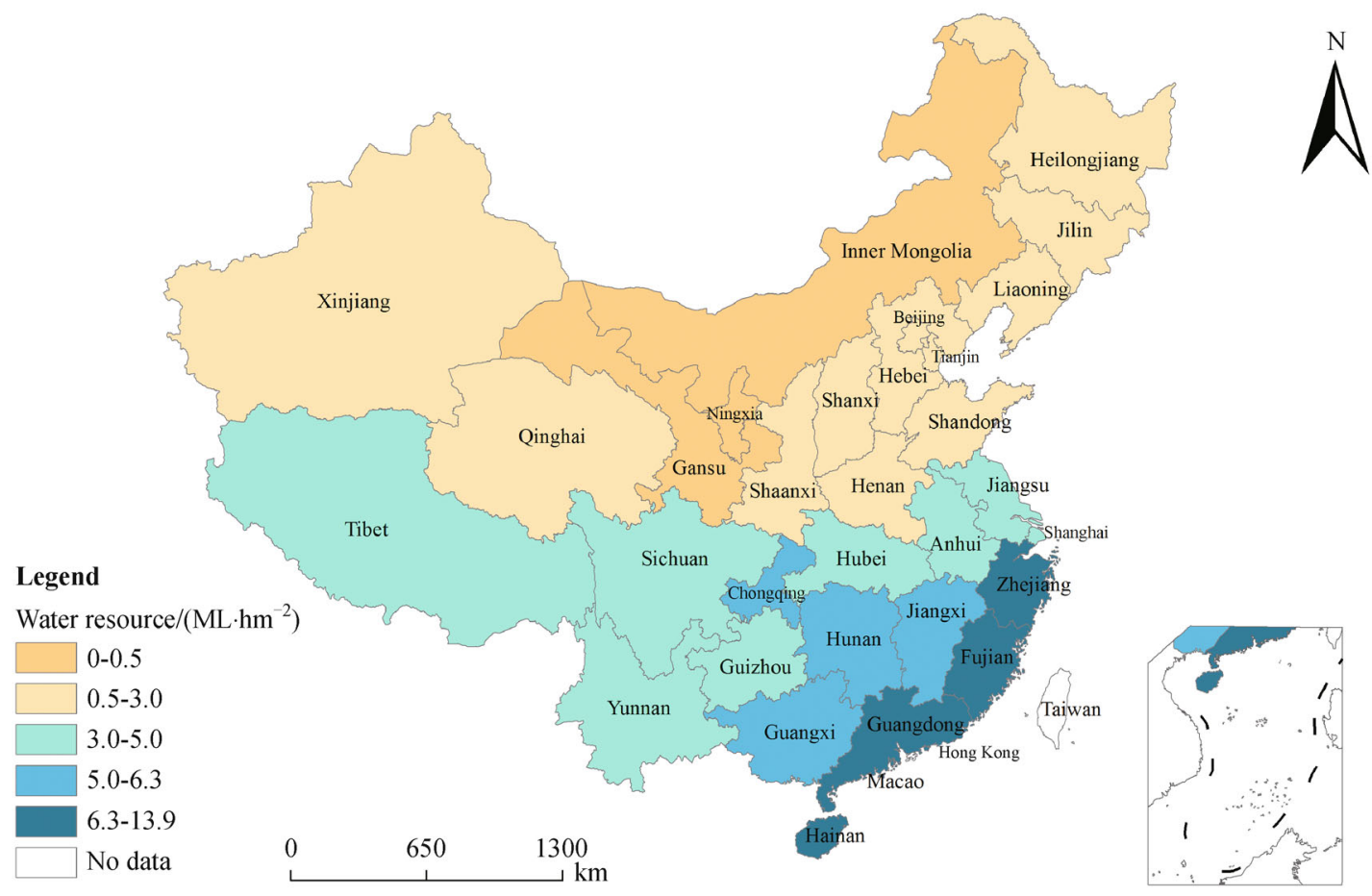

Fig. 5 Distribution of per unit area water resource in China 


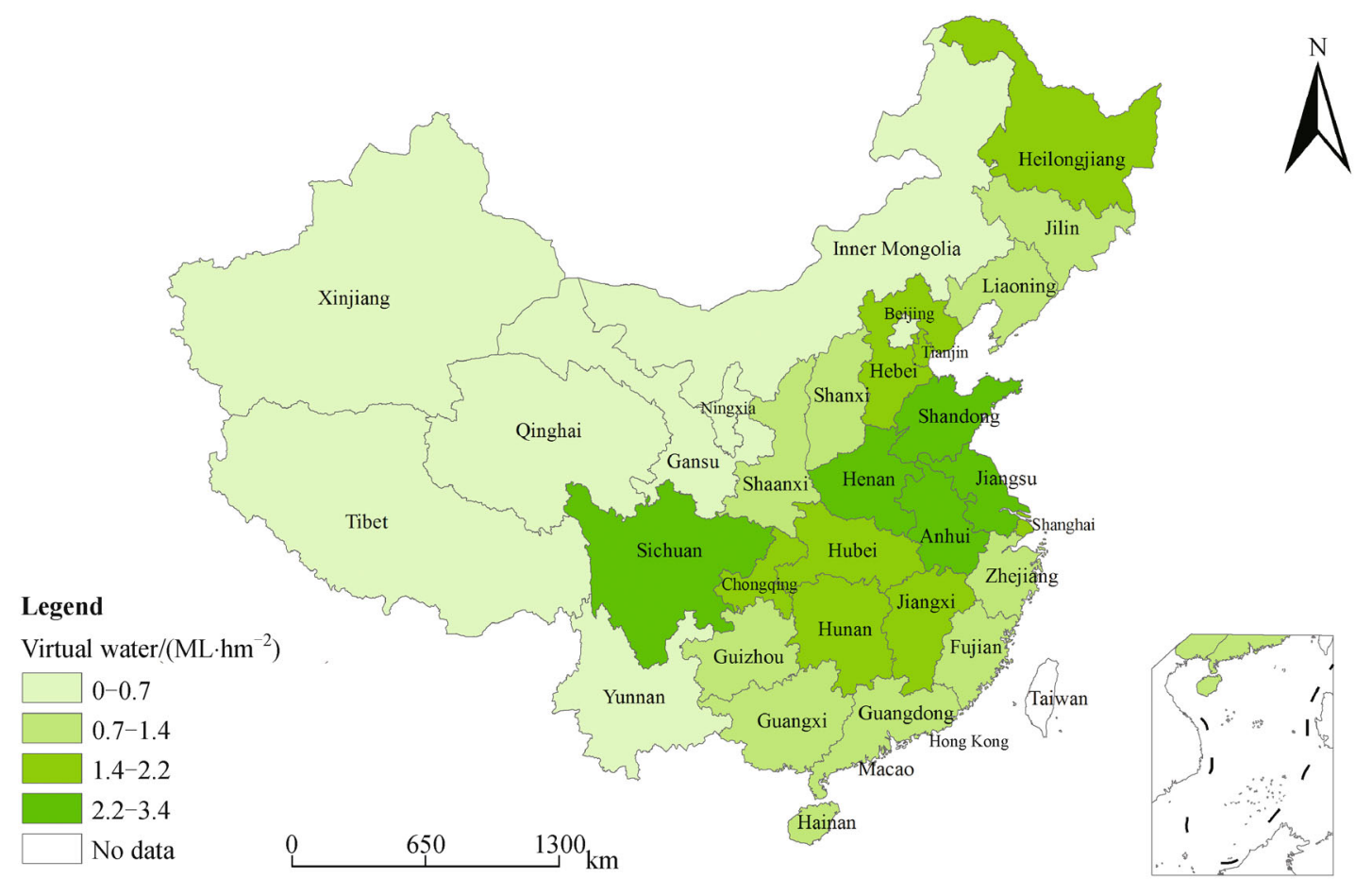

Fig. 6 Distribution of per unit area virtual water in China

where water resources are not abundant, virtual water consumption represent $38 \%$ of the national total. Among them, per unit virtual water in Anhui is $3 \mathrm{ML} \cdot \mathrm{hm}^{-2}$, but is 4.5 times of the average level of China. On the contrary, the southern provinces such as Hainan, Guangdong, Fujian, Zhejiang have the most abundant water of China, but their virtual water represents only $7 \%$ of the national total (Fig. 5 and Fig. 6).

\section{Discussion}

By analyzing China's current agriculture system and its food security situation, some new problems of China's food security were revealed. We discuss below the approaching limits for grain production, the shifting demands on grain produced and inconsistency in water resource utilization. We then propose that a possible solution to these problems would be the development of grassland agriculture in China.

\subsection{Limits to grain production}

As the growth in domestic demand for animal food, the "pig and grain" agriculture system will inevitably face a big increase in demand for feed grain [21]. Our research showed that the FE of total demand of grain would reach $700 \mathrm{Mt}$ in China by 2020, and $70 \%$ of this will be derived from feed grain [22].

However, the potential of grain yield is reaching its limit. Increasing the quantity of cultivated land to increase grain output is impracticable. China's per capita cultivated land is less than half of the world's average level. Even though a policy to preserve 120 million hectares of land for agriculture was set as an absolute minimum to guarantee China's food safety with the explosive growth of Chinese economy and the acceleration of urbanization makes the problem of agricultural land shortage even worse $[23,24]$. Thus, the growth potential of total grain output is approaching a real limit, such that the continued growth of feed grain demand exerts a great pressure on the China's food supply.

4.2 Conflicting demands on grain for human and animal food

Increasing demand for food is an inevitable trend driven by population growth and rising incomes. Despite the great growth in consumption of animal food over the past 20 years, per capita supply of China's animal food is just $50 \%$ of that in the USA and $80 \%$ of that in the South Korea. It is obvious that the demand for animal food will continue to increase and potentially approach the levels in the South Korea and the USA. Even without any population growth, $270 \mathrm{Mt}$ of FE would be needed to reach the level in South Korea given China's existing population of 1.3 billion. It is impossible for the current agricultural system to produce sufficient grain to reach the level of animal food consumption in the USA. The current agriculture system has a dilemma, on one side it must supply grain food to 
feed the huge population, and on the other side it also must meet the rapidly growing demand for animal feed for pigs, poultry and other grain-fed animals.

\subsection{Inconstancies in water resource utilization}

The result of section 3.3 showed the fact of "sending grains from the North to the South" in recent years. Compared to the north of China, the south has better heat and water conditions [25]. Furthermore, to produce a unit of food grain, the consumption of virtual water in the northern drought areas is at least $0.1 \mathrm{~m}^{3}$ more than that in the south [26]. So planting crops in southern China has a higher comparative advantage than in northern China. However, the regions with better heat and water conditions is insufficient of grain food, while the water-shortage places are charged with the most heavy grain food production task in China. China's water resource is very shortage, so only by rational utilizing water resource; agricultural production could be sustainable developed. But in the current agriculture system, the water resource of southern region is idle and the opportunity cost of food production is really high.

4.4 Potential solution through development of grassland agriculture in China

In coming years, China will continue to confront an increasing demand for animal products [27]. The grain farming system in China has limited diversity, and most cropping is rain-fed. The highly variable weather conditions make it increasingly difficult to achieve stable yield in rain-fed cropping systems, especially under a warming global environment. Over the long-term, we will be moving to permanent environmental damage from global warming and loss of biodiversity nationwide. Furthermore, the production of grain is highly dependent on pesticides and chemical fertilizers; the excess use of which has caused ecological problems such as soil erosion, pollution and desertification [28]. Thus, it is doubtful if China's current agriculture system can be sustained and can ensure food security. China is facing the challenge to find a new way to feed its large population and do it in a way that is sustainable environmentally, economically and socially.

In contrast, research shows that grasslands sustain a tremendous diversity of life and provide several ecosystem functions such as soil erosion control, soil fertility improvement, water conservation and protection, wildlife habitat and pollution buffers [27]. Thus, developing grassland agriculture might be a new way to sustainably solve the problem of food security in China.

Compared to grain farming, grassland agriculture may be described as the art and science of cultivating forage crops, pasture and rangelands for food and fiber production [29]. The American Forage \& Grassland Council defines grassland agriculture as "the proper use of grasses in agriculture," though it includes the proper use of legumes and other herbaceous species as well. Both grasses and grass-legume mixtures can be used to feed livestock, support wildlife and to maintain land resources in good condition [30]. Pastures, rangeland, cereal-forage rotation and intercropping are included in grassland agriculture system. The effect of grassland agriculture under artificial control of input and output of energy flow, material flow and information flow is to maximize eco-economic benefits [31].

In facing up to the new problem of China's food security, the implementation of grassland agriculture has the following advantages.

(1) Saving feed grain. There is concern about the use of grains in animal production that could be used to produce food eaten by humans. Due to the tight supply, grain should be used for efficient purposes. In considering the efficiency of animal food production, the quantity of humanly edible energy and protein used in animal feed should be used rather than gross energy efficiency or protein intake/output ratios [32]. The food products from grassland are milk and meat from ruminant animals, which could fed on forage grass. Compared with pigs, poultry and other grain-fed animals, ruminants can improve the grain conversion rate by lower inputs of grains and higher inputs of grass [33], thereby saving feed grain and ease the pressure on food security.

(2) Providing a large number of high-quality animal food. A lot of practices identified that use high-quality legume-grass meal to feed chickens, pigs, cattle, sheep and other livestock can increase livestock production by $10 \%$ to $17 \%$ [34]. Therefore, grassland agriculture system has a larger potential in producing animal food. Furthermore, animal proteins generally have a greater biological value than plant proteins. For example, meat and milk from animals fed mainly on natural grassland usually have lower levels of saturated fat, higher levels of omega-3 fatty acids and conjugated linoleic acid than meat and milk from grain-fed animals [27]. These compounds, sometimes termed healthy fats, have shown anticancer properties in laboratory studies [27].

(3) Utilizing water resources strategically. China is a mountainous country so large areas of land are more suited to growing grass than grain crops. Thus, it can be seen that China has great potential to develop grassland agriculture. Grassland agriculture system could significantly increase the FE output in China, which would not only increase the use of water resources in the south but also alleviate the pressure of water resources in the north.

Additionally, with the recent flow of rural population to urban areas, there is an increasing amout of abandoned land. Developing grassland agriculture could revitalize rural communities by providing a more diverse agriculture with more employment opportunities [27]. Above all, under the new concept of food security, China's current "grain farming" cannot meet the demand for improved 
nutrition and resource utilization, so grassland agriculture is a logical way to ensure China's food and nutrition security.

Acknowledgements Special thanks go to the anonymous reviewer who kindly helped the authors to amend the manuscript to an acceptable level of English. The research was supported by the key consultative project "Ecological security of grassland and food security in China" by Chinese Academy of Engineering (2012-ZD-7) and Program for Changjiang Scholars and Innovative Research Team in University (IRT13019).

Supplementary material The online version of this article at http://dx.doi. org/(doi:10.15302/J-FASE-2014023) contains supplementary material.

Compliance with ethics guidelines Huilong Lin, Ruichao Li, Cangyu Jin, Chong Wang, Maohong Wei and Jizhou Ren declare that they have no conflict of interest or financial conflicts to disclose.

This article does not contain any studies with human or animal subjects performed by the any of the authors.

\section{References}

1. Brown L R. Who will feed China? wake-up call for a small planet. WW Norton \& Company, 1995

2. Brown L R, Halweil B. China's water shortage could shake world food security. World Watch, 1998, 11(4): 10-21

3. Wong J, Huang Y J. China's Food Security and Its Global Implications. China. International Journal, 2012, 10(1): 113-124

4. Sun C Z, Liu Y Y, Chen L X, Zhang L.Analysis on virtual water flows pattern embedded in China's crops trade and its causes- added discussion on the applicability of "virtual water strategy" in China. China Soft Science, 2010(7), 36-44 (in Chinese)

5. CFS. food security indicators. http://www.fao.org/cfs/en/, 2013-1215

6. Toledo A, Burlingame B. Biodiversity and nutrition: A common path toward global food security and sustainable development. Journal of Food Composition and Analysis, 2006, 19(6-7): 477483

7. Frison E A, Cherfas J, Hodgkin T. Agricultural Biodiversity Is Essential for a Sustainable Improvement in Food and Nutrition Security. Sustainability, 2011, 3(12): 238-253

8. Ren J Z, Hou F J. Change traditional thinking about food grain production and use food equivalent in yield measurement. Acta prataculturae sinica, 1999, 8(S1): 55-75 (in Chinese)

9. Ren J Z. The great potential of the model of saving food grassland animal husbandry. Pratacultural Science, 2005, 22(7): 44-48 (in Chinese)

10. Hu X P, Guo X H. Analysis and prediction of China's grain demand structure in 2020-based on the perspective of nutritional standards. Chinese Rural Economy, 2010, (6): 4-15(in Chinese)

11. Fan M S, Shen J B, Yuan L X, Jiang R F, Chen X P, Davies W J, Zhang F S. Improving crop productivity and resource use efficiency to ensure food security and environmental quality in China. Journal of Experimental Botany, 2012, 63(1): 13-24

12. Lu Q S, Xu B, Liang F Y, Gao Z Q, Ning J C. Influences of the Grain-for-Green project on grain security in southern China. Ecological Indicators, 2013, 34: 616-622
13. Liu X M. A discussion on systematic evaluation indicators for food security. Finance \& Trade Economics, 2004 (9): 56-61(in Chinese)

14. Wu W B, Yang P, Tang H J, Zhou Q B, Chen Z X. A new method of food security assesment. Chinese Journal of Agricultural Resources and Regional Planning, 2010, 31(1): 16-21(in Chinese)

15. EViews. http://www.eviews.com/home.html, 2014-3-4

16. Allan J A. Virtual Water: A Strategic Resource Global Solutions to Regional Deficits. Ground Water, 1998, 36(4): 545-546

17. FAO. Food security indicators. http://www.fao.org/economic/ess/ ess-fs/ess-fadata/en/\#.Up_YQ41kyTU, 2013-12-15

18. The development planning department of Ministry of Agriculture. China agricultural outlook at the beginning of new century, China Agriculture Press, 2002 (in Chinese)

19. Sun C Z, Zhang L. Changes in spatial and temporal differences of agricultural product virtual water versus cultivated land in China. Resources Science, 2009, 31(1): 84-93 (in Chinese)

20. Lindeman R L. The trophic-dynamic aspect of ecology. Ecology, 1942, 23(4): 399-417

21. Le Cotty T, Dorin B. A global foresight on food crop needs for livestock. Animal, 2012, 6(9): 1528-1536

22. Ren J Z, Nan Z B, Lin H L. Taking the grassland agro-system to insure food security. Acta prataculturae sinica, 2005, 14(3): 1-10 (in Chinese)

23. Chen J. Rapid urbanization in China: A real challenge to soil protection and food security. Catena, 2007, 69(1): 1-15

24. Jiang L, Deng X Z, Seto K C. The impact of urban expansion on agricultural land use intensity in China. Land Use Policy, 2013, 35: 33-39

25. Huang Q. Changes of food supply- demand pattern and strategic allocation of sunlight, warmth and water resources in China. Acta prataculturae sinica, 2010, 19(2): 1-6 (in Chinese)

26. Liu B Q, Feng Z M, Yao Z J. Theory, Method and Progress on Virtual Water Research. Resources Science, 2006, 28(1): 120-127 (in Chinese)

27. Wedin W F, Fales S L. Grassland: Quietness and strength for a new American agriculture: ASA-CSSA-SSSA, 2009

28. Zhang F S, Chen X P, Vitousek P. Chinese agriculture: an experiment for the world. Nature, 2013, 497(7447): 33-35

29. Barnes R F. Grassland agriculture: serving mankind. Rangelands Archives, 2006, 4(2): 61-62

30. National Forage \& Grasslands Curriculum. Define grassland agriculture, Discuss a typical grassland ecosystem. http://forages. oregonstate.edu/nfgc/eo/onlineforagecurriculum/instructormaterials/availabletopics/introduction/definition, 2013-12-15

31. Tang J, Lin H L. Analysis of characteristics of the circular economy of grassland farming. Acta Prataculturae Sinica, 2013, 22(1): 167175 (in Chinese)

32. Oltjen J, Beckett J. Role of ruminant livestock in sustainable agricultural systems. Journal of Animal Science, 1996, 74(6): 14061409

33. O'Mara F P. The role of grasslands in food security and climate change. Annals of Botany, 2012, 110(6): 1263-1270

34. Li Y T. Ways to ensure food security strategy in China-Developing forage protein feed and reducing grain for feeding stuff. Pratacultural Science, 2009, 26(2): 1-4 (in Chinese) 